\title{
ANGKLUNG TRAINING FOR PAUD TEACHERS
}

\section{Sulastri}

\author{
IKIP Siliwangi
}

lastrinurahwan@gmail.com

\begin{abstract}
West Java is the area that is rich in traditional music, one of them is angklung, which is a musical instrument made of bamboo and played by shaking. As one of the traditional musical instruments, angklung as musical instrument should be maintained by the community so that it can still be heard and played and even preserved to the next generation. One effort to appreciate and preserve angklung traditional music, IGTKI (Bandung Kindergarten Teachers Association) held a Training to improve the professional competence of early childhood education teachers as a target audience in mastering traditional angklung music to be able to transfer knowledge to children early age in PAUD. The purpose of this study analyzed the implementation of angklung extracurricular learning in PAUD in Bandung as a vehicle for the preservation of traditional music in West Java. This study uses qualitative descriptive as the method. Data collection techniques used were observation, interviews, and documentation. By preserving angklung traditional music, it is hoped that angklung music will remain a cultural heritage of West Java without fear of being seized by other countries.
\end{abstract}

Keywords: Training, Education Teachers, PAUD, Angklung

\section{INTRODUCTION}

Training is an activity to give, obtain, improve, and develop a work ethic at the level of skills and expertise in accordance with job qualifications. Training for early childhood educators is designed to complement PAUD teachers and in the playground, so they have adequate knowledge and skills in applying the basic of early childhood education, that is accordance with aspects of child development. The Training Program will also strengthen teacher skills in developing personality competencies, social competencies, professional competencies and pedagogical competencies accordance with Minister of Education Regulation No. 12 of 2007.

One of the most decisive factors in the effort to improve the quality of human resources through education is the educators (teachers), through them education is implemented at the micro level, it means that how the quality of education and learning outcomes will lie in how educators carry out their duties professionally and based on values of life that are not only material values but also transcendent values that can inspire the educational process towards an ideal and meaningful condition for the student happiness life, educators and society as a whole.

Thus, it appears that Educators are expected to have a significant influence on the formation of human resources in cognitive, affective and skill aspects, both in physical, mental and spiritual aspects. This clearly demands the quality of the provision of good education and professional educators, so that the quality of educational outcomes can truly play an optimal 
role in people's lives. For that educators are required to improve, develop themselves in building the world of education.

By remembering the serious and complexity of developing education, it is very important to make efforts to encourage and empower educators to become more professional and encourage the public to active participate in providing space for educators to actualize themselves in order to develop education, this is nothing but intended to make efforts to build a solid education, and be able to continuously make improvements towards higher quality.

In line with this, the Bandung City Kindergarten Teacher Association have an active role in increasing the competence of PAUD teachers, as part of human resources which has become a leading indicator in measuring and describing the progress of a nation, on that basis every country has placed the development of resources humans as the main development issues, programs and strategies, including Indonesia. Through Angklung Training activities, it is hoped that PAUD teachers will increasingly know their responsibility is really great because early childhood in their hands is the next generation of the nation so that they will be increasing to provide maximum service to children.

Various studies related to early childhood show that the preparation of quality human resources must be started from an early age, even from the conception period in the womb. Knowing of the needs of children's development and growth greatly determines the quality of health, intelligence, and social maturity in the next stage. So at that age a nurturing and guidance effort is needed for children through the provision of educational stimuli to help the physical and spiritual growth of children so that they will have readiness in entering further education in the future.

Early childhood education, hereinafter abbreviated as PAUD, is an effort to guide children from birth to the age of 6 (six) years through the provision of educational stimuli to help growth and physical and spiritual development so that children have readiness to enter further education. (Rohaeni, 2014). Some of the components that can be elaborated from the formulation above, namely: (1) PAUD contains a training program in the form of educational activities, (2) PAUD targets are children aged 0-6 years, (3) PAUD programs to develop all potential children that cover the scope the development of religious and moral values, motoric, cognitive, linguistic, social emotional, and artistic, (4) The purpose of the PAUD program is to have readiness for further education for chidren.

Early childhood education in Indonesia has special characteristics compared to those applied in various countries. the particularity lies in: (1) the range of age ranges, the target of early childhood in Indonesia from 0 - 6 years, while in many countries reaching the age of 8 years; (2) early childhood service programs in Indonesia consist of kindergarten (for children 4-6 years), playgroups (priority for children aged 2-4 years), child care parks (priority age 0-6 years), and Similar PAUD Unit (children 0-6 years old); (3) education pathways: Kindergarten is included in the formal education pathway, while Playgroups, Child Care Parks, and Similar Early Childhood Education Units are included in the path of non-formal education. This particularity makes PAUD in Indonesia specific in its implementation because each service program has its own distinctiveness. However, all PAUD service programs have the same goal, namely to develop all the potential of children which includes aspects of religious and moral values, physical motor, cognitive, language, social emotional, and art to achieve readiness for further education, (Purwaningsih, 2014). Early childhood education is the basis that has a real influence on the success in the education level above. 
Therefore, early childhood education is developed based on a scientific foundation, a judicial foundation, social, cultural, and pedagogical both theoretically and empirically.

In this regard, great responsibility is born by PAUD teachers to develop all the potential possessed by children, so the Association of Indonesian Kindergarten Teachers in Bandung City feels the need to integrate local cultures in West Java to be applied through Playground or PAUD that has a love of traditional Angklung music.

One of the traditional musical instruments of West Java is angklung made of bamboo stems, first introduced by Daeng Soetigna around 1938 in West Java. The word angklung comes from the Sundanese language "angkleung-angkleungan" which is the movement of the angklung player and the sound produced is "klung". The way to play angklung instrument is to shaking, so that it will produce sound of the angklung appears because the bamboo collides with each other. The sound produced by the collisions of the bamboo forms the arrangement of the tones (Indrawaty, Ichwan, \& Erlangga, 2013). According to Udjo dalam (Komariyah, 2016), that angklung can arouse attention to music, revive musicality, develop a sense of rhythm, melody, harmony, development of intelligence, and creativity. Angklung can be means of channeling emotions, expressions of happiness in playing music, as well as exercising gesture coordination when following the rhythm of music in the framework of developing psychomotor nerves.

Angklung music training activity provides a method that is very easy to remember by teachers or PAUD children, one of them is the finger method (Koda'ly method), this is felt to be very important for the teacher to facilitate delivery in introducing and playing angklung instruments with the child PAUD children.

\section{RESEARCH METHODS}

The method of this research is survey. Data collection was carried out by direct interviews with respondents of PAUD teachers who participated in angklung training as representatives of each playground and PAUD in Bandung as many as 35 PAUD teachers. Data analysis was carried out descriptive qualitative. This research was carried out in the Bandung Wetan subdistrict teacher working group (TK Istiqamah street Citarum Park). The Site selection because the subdistrict cluster is the center of teacher activities and meetings every week, after each school's learning activities completed.

\section{RESULTS AND DISCUSSION}

\section{Results}

The training organized by the Bandung City Kindergarten Teachers Association, which is devoted to PAUD teachers, aims to participate in preserving the West Java arts culture, namely angklung traditional music so that it is not extinct and is not recognized by other countries, therefore according to the child's development that children are born with their own potential and can be stimulated early by inviting children to love, listen and play this angklung instrument while playing.

On the below, it showed before the teacher gets angklung training using the Koda'ly method and after getting angklung training using the Koda'ly method. 
Table 1. The ability of the teacher to play angklung before getting training with the Koda'ly method

\begin{tabular}{|c|c|c|c|c|}
\hline $\begin{array}{l}\text { No } \\
\text { Son }\end{array}$ & $\begin{array}{l}\text { Teacher Code } \\
\text { eading }\end{array}$ & How $t$ & & How to ring angklung \\
\hline 1 & A-01 & $\mathrm{BB}$ & $\mathrm{BB}$ & $\mathrm{BB}$ \\
\hline 2 & A-02 & $\mathrm{BB}$ & $\mathrm{BB}$ & MB \\
\hline 3 & A-03 & MB & MB & MB \\
\hline 4 & A-04 & MB & $\mathrm{BB}$ & $\mathrm{BB}$ \\
\hline 5 & A-05 & $\mathrm{BSH}$ & $\mathrm{MB}$ & $\mathrm{BSH}$ \\
\hline 6 & A-06 & BB & BB & MB \\
\hline 7 & A-07 & $\mathrm{BSH}$ & MB & MB \\
\hline 8 & A- -08 & $\mathrm{BB}$ & $\mathrm{BB}$ & $\mathrm{BB}$ \\
\hline 9 & A-09 & MB & MB & MB \\
\hline 10 & A-10 & BB & $\mathrm{BB}$ & $\mathrm{BB}$ \\
\hline 11 & A-11 & $\mathrm{BB}$ & $\mathrm{BB}$ & $\mathrm{BB}$ \\
\hline 12 & A-12 & BSH & MB & MB \\
\hline 13 & A-13 & $\mathrm{BB}$ & $\mathrm{BB}$ & $\mathrm{BB}$ \\
\hline 14 & A-14 & $\mathrm{BSH}$ & MB & $\mathrm{BSH}$ \\
\hline 15 & A-15 & $\mathrm{BB}$ & $\mathrm{BB}$ & $\mathrm{BB}$ \\
\hline 16 & A-16 & MB & $\mathrm{MB}$ & MB \\
\hline 17 & A-17 & $\mathrm{BB}$ & $\mathrm{BB}$ & $\mathrm{BB}$ \\
\hline 18 & A-18 & MB & MB & MB \\
\hline 19 & A-19 & $\mathrm{BB}$ & $\mathrm{BB}$ & BB \\
\hline 20 & A-20 & MB & $\mathrm{MB}$ & MB \\
\hline 21 & A-21 & BB & BB & BB \\
\hline 22 & A-22 & BB & BB & BB \\
\hline 23 & A-23 & BSH & BSH & BSH \\
\hline 24 & A-24 & BSH & BSH & BSH \\
\hline 25 & A-25 & MB & BB & BB \\
\hline 26 & A-26 & BB & BB & BB \\
\hline 27 & A-27 & BSH & BSH & BSH \\
\hline 28 & A-28 & MB & BB & BB \\
\hline 29 & A-29 & $\mathrm{BSH}$ & BSH & BSH \\
\hline 30 & A-30 & BB & BB & BB \\
\hline 31 & A-31 & MB & $\mathrm{BB}$ & $\mathrm{BB}$ \\
\hline 32 & A-32 & BB & BB & BB \\
\hline 33 & A-33 & MB & $\mathrm{MB}$ & BSH \\
\hline 34 & A-34 & BB & BB & BB \\
\hline 35 & A-35 & $\mathrm{BSH}$ & BSH & BSH \\
\hline
\end{tabular}


Table 2. Recapability of the Teacher's ability to play angklung before getting training with the Koda'ly method

\begin{tabular}{cccccc}
\hline reading & \multicolumn{2}{c}{ How to hold angklung } & How to ring angklung & Song \\
\hline BB & 16 & 20 & 57,1 & 18 & 51,5 \\
& 45,7 & & & & \\
MB & 10 & 10 & 28,6 & 9 & 25,7 \\
& 28,6 & & & & \\
BSH & 9 & 5 & 14,3 & 8 & 22,8 \\
& 25,7 & & & & \\
\hline TOTAL & 35 & 35 & 100 & 35 & 100 \\
\hline
\end{tabular}

From the table above, there were 16 indicators for how to hold angklung that had not yet developed, which began to develop by 10 teachers and it developed according to the expectations of 9 teachers. For the value of the indicator how to ring the angklung, there were 20 undeveloped teachers, who started to develop as many as 10 teachers and those that developed according to expectations were 5 teachers. For indicators of reading song scores, there were 18 undeveloped teachers, who started to develop as many as 9 teachers and those who had developed as expected were 8 teachers.

Table 3. Teacher's ability to play angklung after getting training with the Koda'ly method

\begin{tabular}{|c|c|c|c|c|}
\hline $\begin{array}{l}\text { No } \\
\text { Song }\end{array}$ & $\begin{array}{l}\text { Teacher Code } \\
\text { reading }\end{array}$ & How to hold angklung & & How to ring angklung \\
\hline 1 & A-01 & $\mathrm{BSH}$ & $\mathrm{BSH}$ & BSH \\
\hline 2 & $\mathrm{~A}-02$ & $\mathrm{BSH}$ & $\mathrm{BSH}$ & BSH \\
\hline 3 & $\mathrm{~A}-03$ & $\mathrm{BSH}$ & MB & $\mathrm{BSH}$ \\
\hline 4 & A-04 & $\mathrm{BSH}$ & $\mathrm{BSH}$ & $\mathrm{BSH}$ \\
\hline 5 & A-05 & BSH & $\mathrm{BSH}$ & BSH \\
\hline 6 & A-06 & MB & $\mathrm{BSH}$ & MB \\
\hline 7 & A-07 & $\mathrm{BSH}$ & $\mathrm{BSH}$ & $\mathrm{BSH}$ \\
\hline 8 & A-08 & BSH & $\mathrm{BSH}$ & BSH \\
\hline 9 & A-09 & BSH & BSH & BSH \\
\hline 10 & A-10 & MB & $\mathrm{BSH}$ & MB \\
\hline 11 & A-11 & $\mathrm{BSH}$ & $\mathrm{BSH}$ & $\mathrm{BSH}$ \\
\hline 12 & A-12 & $\mathrm{BSH}$ & $\mathrm{BSH}$ & $\mathrm{BSH}$ \\
\hline 13 & A-13 & $\mathrm{BSH}$ & $\mathrm{BSH}$ & $\mathrm{BSH}$ \\
\hline 14 & A-14 & BSH & $\mathrm{BSH}$ & BSH \\
\hline 15 & A-15 & $\mathrm{BSH}$ & $\mathrm{BSH}$ & $\mathrm{BSH}$ \\
\hline 16 & A-16 & $\mathrm{BSH}$ & $\mathrm{BSH}$ & $\mathrm{BSH}$ \\
\hline 17 & A-17 & BSH & MB & BSH \\
\hline 18 & A-18 & $\mathrm{BSH}$ & $\mathrm{BSH}$ & $\mathrm{BSH}$ \\
\hline 19 & A-19 & $\mathrm{BSH}$ & $\mathrm{BSH}$ & BSH \\
\hline 20 & A-20 & $\mathrm{BSH}$ & $\mathrm{BSH}$ & $\mathrm{BSH}$ \\
\hline 21 & A-21 & BSH & $\mathrm{BSH}$ & BSH \\
\hline 22 & A-22 & BSH & $\mathrm{BSH}$ & BSH \\
\hline
\end{tabular}




\begin{tabular}{lllll}
\hline $\begin{array}{l}\text { No } \\
\text { Song }\end{array}$ & $\begin{array}{c}\text { Teacher Code } \\
\text { reading }\end{array}$ & How to hold angklung & How to ring angklung \\
\hline $\mathbf{2 3}$ & A-23 & BSH & BSH & BSH \\
\hline $\mathbf{2 4}$ & A-24 & BSH & BSH & BSH \\
\hline $\mathbf{2 5}$ & A-25 & BSH & BSH & BSH \\
\hline $\mathbf{2 6}$ & A-26 & BSH & BSH & BSH \\
\hline $\mathbf{2 7}$ & A-27 & BSH & BSH & BSH \\
\hline $\mathbf{2 8}$ & A-28 & BSH & BSH & BSH \\
\hline $\mathbf{2 9}$ & A-29 & BSH & MB & BSH \\
\hline $\mathbf{3 0}$ & A-30 & BSH & BSH & BSH \\
\hline $\mathbf{3 1}$ & A-31 & BSH & BSH & BSH \\
\hline $\mathbf{3 2}$ & A-32 & BSH & BSH & BSH \\
\hline $\mathbf{3 3}$ & A-33 & BSH & BSH & BSH \\
\hline $\mathbf{3 4}$ & A-34 & BSH & BSH & BSH \\
\hline $\mathbf{3 5}$ & A-35 & BSH & BSH & BSH \\
\hline
\end{tabular}

$\mathrm{BB}=$ Not Developing yet, $\mathrm{MB}=$ Start Growing, $\mathrm{BSH}=$ Developing as Expected

Table 4. Recapability of Teachers to play angklung after getting training with the Koda'ly method

\begin{tabular}{|c|c|c|c|c|c|c|}
\hline reading & \multicolumn{3}{|c|}{ How to hold angklung } & \multicolumn{2}{|c|}{ How to ring angklung } & Song \\
\hline $\mathrm{BB}$ & 0 & 0 & 0 & & 0 & 0 \\
\hline MB & 2 & 5,7 & $6^{3}$ & & 2 & 5,7 \\
\hline BSH & 33 & 94,3 & & & 33 & 94,3 \\
\hline TOTAL & 35 & 100 & 35 & 100 & 35 & 100 \\
\hline
\end{tabular}

From the table above, there are 0 indicators for how to hold angklung that have not been developed, which began to develop as many as 2 teachers and which developed according to the expectations of 33 teachers. For the value of the indicator how to ring the angklung, there were 0 undeveloped teachers, who began to develop as many as 3 teachers and those that developed according to expectations were 32 teachers. For the music score reading indicators, there were 0 undeveloped teachers, who started to develop as many as 2 teachers and those who had developed according to expectations were 33 teachers. 
Table 5. Comparison between the teacher's ability to play angklung before and after getting angklung training using the Koda'ly method

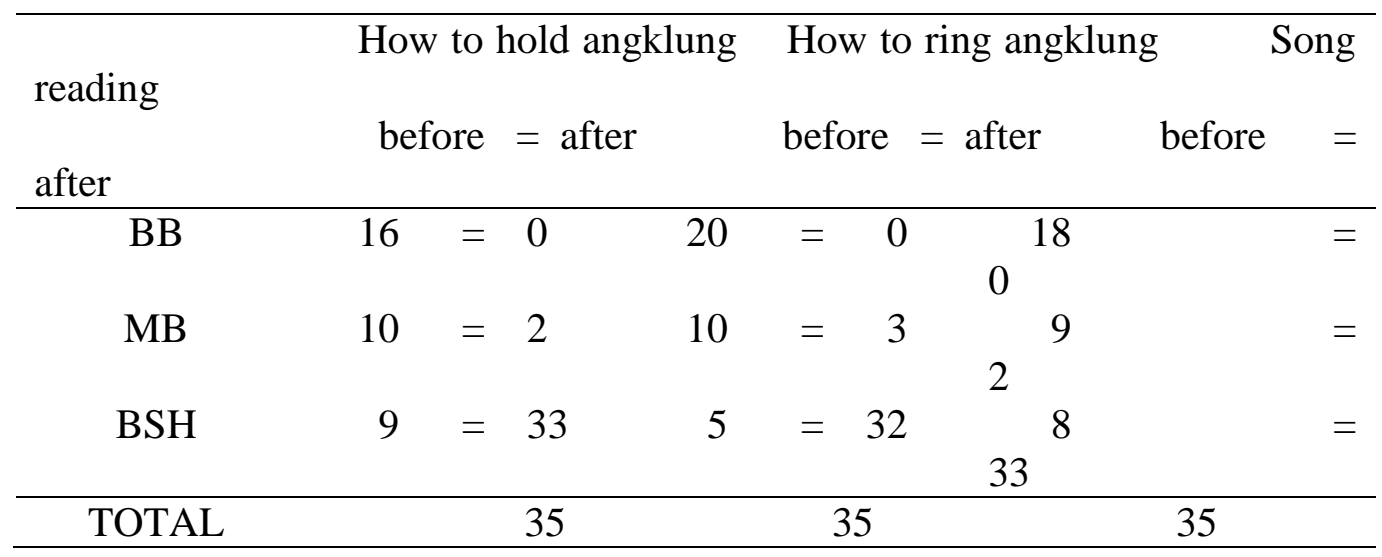

- The comparison table between the ability of teachers to play traditional musical instruments Angklung before and after getting training is as follows: The ability of teachers to hold angklung musical instruments that have not yet developed there are 16 people then after training all participants can hold the angklung instrument correctly, who initially started Berkembang with 10 people, after the training left behind 2 people, and for the value that developed according to expectations from the beginning 9 people rose to 33 people.

- The ability of the teacher to ring the angklung musical instrument which had not yet developed there were 20 people, so after the training all participants could hold the angklung instrument correctly, which initially began to develop there were 10 people, then after the training there were 3 people left behind, and for the value that developed according to the expectations of initially 5 people rose to 32 people.

- The ability of the teacher to read music scores that initially did not develop there were 18 people, so after training all participants were able to read song scores, which initially had 9 people, then after the training there were 2 people left behind, and for developing values according to expectations 8 people rose to 33 people.

\section{Discussion}

Angklung training for PAUD teachers organized by the Bandung City Kindergarten Teachers Association aims to help preserve the traditional culture of West Java, especially to know traditional angklung music that will be transferred to early childhood in the playground or in PAUD. Early childhood teachers who were not able to hold angklung at first, sounded angklung instruments with sound origin and many were unable to read song scores correctly, so after getting angklung training from angklung community trainers, the teachers had skills in holding angklung correctly, can sound an angklung instrument according to the correct rules, can read music scores correctly and can apply between musical notes in the form of solmizing notes into the hand signing movement (Koda'ly method), the following will be compared to the ability of PAUD teachers before getting training and after getting angklung training.

The method given during this training is by using the hand (hand signing), better known as the Koda'ly method. Lots of skills that must be possessed by PAUD teachers to master music art one of which is the ability to read solmization notation. The ability to read solmization 
notation is one of the abilities in the field of music art including angklung music that must be mastered by the teacher, solmization itself means to put different syllables into each note on a musical scale. The solmization system used worldwide is the solmization system from Guido (Susilo, 2004, p. 36). Guido's solmization system, Do, Re, Mi, Fa, Sol, La, Si, Do 'was changed into a hand signing using easy-to-remember finger patterns and of course can be introduced to PAUD teachers and children while playing -main. PAUD teachers are asked to repeat the solmization system in hand signing both individually and in groups, can also be performed by playing a song followed by hand movements with the method Koda "ly.

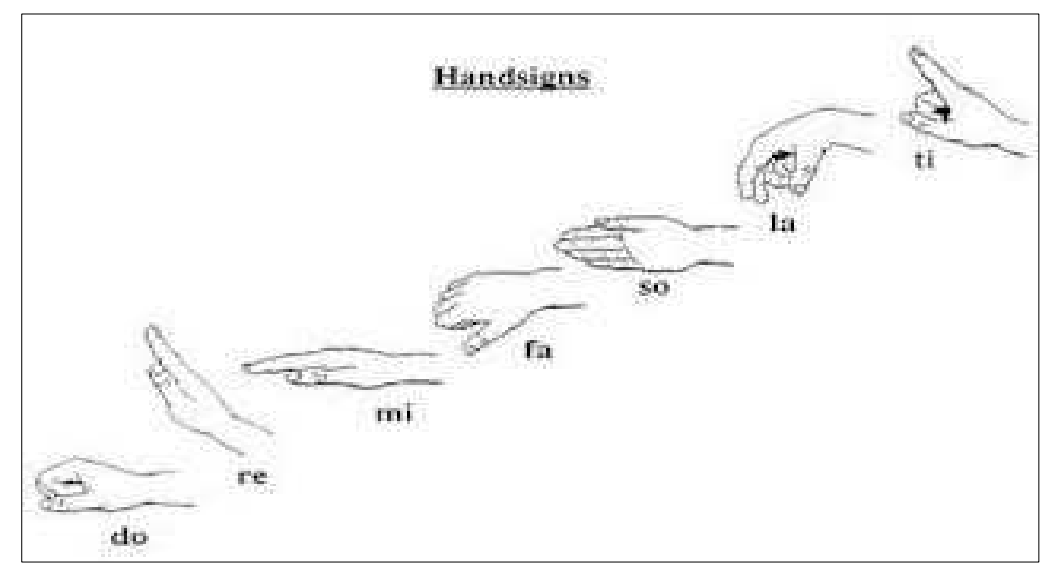

Picture 1. Hand Signing

Source : http://profileengine.com/group/profile/42130660/its-not-gang-sign-it-Koda'ly

The repetition of the hand signing demonstration is intended for PAUD teachers to quickly accept and understand and be able to read song scores with their solmization system. Not only taught how to demonstrate hand signing, but also taught how to hold a correct angklung instrument by way of the left hand straightened parallel to the chest, while the right hand holds the angklung which has a higher tube on the right, the lower tube is on the left, while the position of the thumb and forefinger are united like a movement will pinch something and placed under the base of the angklung. The way to ring the angklung instrument is by shifting the right hand towards the left and right alternately according to the appearance of the solicitation note according to the direction of the conductor or song conductor. The way to play angklung is only shaken and the movement of wiggling angklung trains motorics and is played in groups, the nature of angklung that must be played in groups makes angklung cannot be played independently, (Janir, 2012).

In the beginning not all PAUD teachers were able to sound angklung instruments correctly, but as long as the angklung could sound, regardless of how they should hold and sound the angklung instruments correctly, not all PAUD teachers could read the solmization system properly. This training is very useful for early childhood teachers who in their daily lives are required to be able to sing a song according to the solmization scales correctly.

The world of PAUD children is the creation of play. Every child has an instinct to play, so the need to creativity in a certain pattern that greatly helps the process of growth and development. Playing is the whole activity carried out by someone who is pleasant, encouraging, and creates pleasure which serves to help individuals achieve complete 
development, both physical, intellectual, social, moral and emotional. Playing activities are very interesting activities for children, in a large Indonesian dictionary published by the Ministry of Education and Culture it means that playing from the word play means "to play games that are pleasing by using a game or not", in another sense explained further that playing is "doing deeds for fun by using certain tools or not" (Nurdiani, 2013). Playing on children means to learn because for children playing and learning is a unity and a process that continues happening in his life. Through play, children can organize various experiences and cognitive abilities in an effort to rearrange their beautiful ideas. In other words, playing is the initial stage of the learning process in children that is experienced by all humans, Purwaningsih (2014). Playing is the most basic child's needs, when children interact with the surrounding world, through playing it does. Playing is the main tool to achieve growth, as a medium will try not only fantasy but is done real (Ningsih, 2013).

\section{CONCLUSION}

Based on the description above, it can be concluded that the ability of PAUD teachers to receive angklung training delivered by angklung paguyuan trainers who initially held angklung instruments was only in the form of origin, so after getting training, the teacher learned that the way to hold angklung was the next hand left aligned parallel to the chest, while the right hand holds the angklung which has a higher tube on the right, the lower tube is on the left, while the position of the thumb and forefinger are united like the movement will pinch something and placed under the base of the angklung. The way to ring an angklung instrument is by shifting the right hand towards the left and right in accordance with the solution according to the direction of the conductor or song conductor, and PAUD teachers getting better at reading the solmization of a song. Hopefully the angklung training will make angklung traditional music more attractive to young people through the hands of PAUD teachers.

\section{REFERENCE}

Rohaeni, E. (2014). Penerapan Metode Bermain Balok Dalam Mengembangkan Nilai Kognitif Anak Usia Dini Pada PAUD Nuansa Kota Bandung. Empowerment, 4(2252), 181-197.

Purwaningsih, E. (2014). Penggunaan Metode Bermain Dengan Teknik Leader Conference Dalam Upaya Meningkatkan Kecerdasan Linguistik Anak Usia Dini Di Taman KanakKanak Cendekia Leadership School Kecamatan Cimenyan Kabupaten Bandung. Jurnal Empowerment, 4(2252), 106-119.

Indrawaty, Y., Ichwan, M., \& Erlangga, A. (2013). Pengembangan Simulasi Pola Memainkan Angklung. Jurnal Informatika, $12-20$. https://doi.org/10.1017/CBO9781107415324.004

Komariyah, L. (2016). Pengaruh Musik Angklung Terhadap Kualitas Hidup Wanita Lanjut Usia. Jurnal Pendidikan Keperawatan Indonesia, 2(1), 10-15.

Nurdiani, Y. (2013). Penerapan Prinsip Bermain Sambil Belajar Dalam Mengembangkan Multiple Intelegencia Pada Pendidikan Anak Usia Dini. Empowerment, 2(2252), 85-93.

Ningsih, E. (2013). Penggunaan Metode Bermain Peran Dalam Menumbuhkan Keterampilan Berbahasa Anak Usia Dini. Empowerment, 2(2252), 126-136.

Janir, Z. V. (2012). Penentuan Distribusi Angklung Berdasarkan Partitur Menggunakan Algoritma Pencarian A *. Sarjana Institut Teknlogi Bandung, 1(2). 